\title{
Inspiratory Reserve Volume
}

National Cancer Institute

\section{Source}

National Cancer Institute. Inspiratory Reserve Volume. NCI Thesaurus. Code C111237.

The maximum volume of air a subject can inhale into the lungs after a tidal inhalation. 